\title{
A QUALITATIVE STUDY OF FACTORS AFFECTING THE CONTRACTIONS OF THE EPIDIDYMIS AND DUCTUS DEFERENS OF THE RAM
}

\author{
T. W. KNIGHT \\ Department of Animal Science and Production, Institute of Agriculture, \\ University of Western Australia, Nedlands, W.A. 6009, Australia
}

(Received 21st August 1973)

\begin{abstract}
Summary. Contractions of the ram ductus deferens-epididymis and epididymis were recorded by cannulating these ducts and measuring the intraluminal pressure changes. The intravenous injection of 0.3 to $10 \mathrm{i} . \mathrm{u}$. oxytocin or 10 to $40 \mu \mathrm{g}$ adrenaline, or mechanically increasing the pressure within the ducts, stimulated contractions and increased the tonus in the ductus deferens-epididymis. The duration of the response to 2 to 10 i.u. oxytocin was 20 to $70 \mathrm{~min}$. The response to adrenaline and low doses of oxytocin were of a much shorter duration. Vasopressin was $1 / 15$ th to $1 / 20$ th as potent as oxytocin.

The response to oxytocin was not inhibited by adrenaline, $\alpha$ - or $\beta$ blocking agents or by atropine. In contrast, an $\alpha$-receptor-blocking agent (phentolamine) inhibited the response to adrenaline.

Copulation initiated contractions of the ductus deferens-epididymis which were similar to the response to intravenous adrenaline. Contractions continued for only a short period after the end of copulation, suggesting that there had been little or no release of oxytocin during copulation.
\end{abstract}

\section{INTRODUCTION}

From direct observation of the epididymis and ductus deferens of the rabbit in vivo, Bereznev (1963) recorded that oxytocin increased the contractions of these organs, while Cross (1959) found oxytocin had no effect on the contractions. The only measurement of the contractions of the smooth circular muscles of the epididymis and ductus deferens has been made by Melin (1970a, b) in the rabbit. He found that while low doses of oxytocin enhanced the amplitude of contractions of the epididymis and ductus deferens, high doses had no effect. Melin (1970b) also found that vasopressin was more effective than oxytocin in stimulating contractions of the epididymis and ductus deferens in the rabbit.

It has been suggested by Cross (1966) and Melin (1970c) that oxytocin may be released during copulation. This oxytocin, by stimulating contractions in the epididymis and ductus deferens, could increase the rate of passage of spermatozoa into the distal parts of the genital tract where they would accumulate before ejaculation. The intravenous injection of oxytocin has been found to increase the output of semen from the ram (Knight \& Lindsay, 1970; 
Knight, 1974), bull and rabbit (Milovanov, Bereznev \& Gorohov, 1962; Fjellström, Kihlström \& Melin, 1968).

The epididymis and ductus deferens have a dense adrenergic innervation of their muscular layers, and some species have special chromaffin cells, containing large amounts of catecholamines, in the ductus deferens (Sjöstrand, 1965; Norberg, Risley \& Ungerstedt, 1967). This adrenergic innervation is important in controlling the contractions of the epididymis and ductus deferens during emission (Cross \& Glover, 1958) and the movement of spermatozoa down the epididymis (Simeone, 1933).

In the two experiments presented in this paper, the method described by Melin (1970a) for measuring the isometric contractions of the circular smooth muscles in the epididymis and ductus deferens by recording the intraluminal pressure changes in these organs was adapted for use in anaesthetized and conscious rams. The first experiment examined the effect of mechanical stimulation, oxytocin, vasopressin, adrenaline and pilocarpine on the contractions of the epididymis and ductus deferens of the ram. A preliminary report of this work has been presented (Knight, 1972a). In the second experiment, the characteristics of the isometric muscular contractions in the ductus deferensepididymis of the ram during copulation were compared with the contractions induced by administration of neurohypophysial and other hormones.

\section{MATERIALS AND METHODS}

The jugular vein of the ram was cannulated, and the ram was kept in an anaesthetized state by intravenous infusion of sodium pentobarbitone. The epididymis and ductus deferens were exposed through a longitudinal incision on the posterior surface of the scrotum. The cannula, PP 10 polythene tubing (Portex $0.28 \mathrm{~mm}$ i.d. and $0.61 \mathrm{~mm}$ o.d.) filled with $3 \%$ sodium citrate, was connected to a Sanborn pressure transducer (267 BC) and preamplifier (350 to $3000 \mathrm{c}$ ) and the pressure changes were recorded on a Ricken Denshi recorder.

Recordings from the conscious ram were made with the ram in a $0.6 \times 1.3 \mathrm{~m}$ pen, with the instruments behind the ram and a long piece of PP 10 tubing connecting the pressure transducer to the cannula.

\section{Experiment 1}

Two types of cannulation were used.

(1) Ductus deferens-epididymis cannulation. A transverse incision was made in the ductus deferens $4 \mathrm{~cm}$ from the cauda epididymidis. The cannula was pushed down the ductus deferens until its convolutions impeded further progress. Ligatures were placed $1 \mathrm{~cm}$ from the tip of the cannula to hold it in place. The response measured reflected the combined contractions of the lower part of the ductus deferens and the epididymis.

(2) Epididymis cannulation. A small section of the cauda epididymidis was dissected free and cannulated. This type of cannula measured the response of the epididymis alone. The epididymis is very weak and broke when the ram moved, so no recordings could be made in the conscious ram.

Ten rams were cannulated. Some of the rams were used for more than one 
type of cannulation. Measurements were recorded from the anaesthetized rams for 4 to $5 \mathrm{hr}$. The rams were then allowed to regain consciousness and recording commenced $12 \mathrm{hr}$ later on the conscious rams and continued intermittently for 1 to 4 days.

The drugs tested for their stimulatory or inhibitory effect on the contractile activity and the dose range used were: oxytocin (Pitocin, Parke Davis), 0.3 i.u. to 10 i.u.; vasopressin (Synthetic Grade 1-S, Sigma), 5 i.u. to 20 i.u.; adrenaline (B.D.H.), $10 \mu \mathrm{g}$ to $40 \mu \mathrm{g}$; atropine (B.D.H.), $10 \mathrm{mg}$; pilocarpine (Sigma), $50 \mu \mathrm{g}$ to $100 \mu \mathrm{g}$; phentolamine (Regitine, C.I.B.A.), $10 \mathrm{mg}$ to $15 \mathrm{mg}$; oxprenolol (Trasicor, C.I.B.A.), $1 \mathrm{mg}$ to $2 \mathrm{mg}$; propranolol (Inderal, I.C.I.), $1 \mathrm{mg}$ to $2 \mathrm{mg}$. Only the lower doses of oxytocin approached physiological levels. The doses of the other drugs tested were in the pharmacological range. All drugs were injected through the indwelling jugular cannula. Results were based on a minimum of three responses for each dose level of each drug, tested on at least two different rams.

\section{Experiment 2}

An oestrous ewe, restrained in a 'crush', was placed in a pen in front of the ram and the ram was allowed to copulate with the ewe while the pressure changes in the ductus deferens-epididymis were recorded.

The copulations were divided into four phases: (1) sexual stimulation, which consisted of all the stages of courtship described by Banks (1964), (2) mounting, (3) ejaculation, (4) post-ejaculation, when the ram stood quietly behind the ewe.

The muscular contractions were recorded in six rams during copulation and recordings were made on at least 2 consecutive days.

\section{RESULTS}

The responses of conscious and anaesthetized rams were indistinguishable so that no differentiation was made between them in the results. It was found that the lower amplitude of muscular contractions in the anaesthetized rams compared to those in the conscious rams, and the decline in the response to the same dose of oxytocin previously reported (Knight, 1972a) were eliminated when the testis was maintained at body temperature by returning the testis to the scrotum or bathing the testes with warm physiological saline. All recordings presented in this paper were made with the testis in the scrotum or bathed in warm physiological saline.

\section{Experiment 1. Rams with their ductus deferens-epididymis cannulated}

Spontaneous muscular contractions and mechanical stimulation. In a few observations, spontaneous contractions were present immediately after the cannula was connected to the pressure transducer. These contractions continued for only 5 to $10 \mathrm{~min}$, after which there were no further spontaneous contractions.

Mechanical stimulation of the ductus deferens-epididymis by flushing 0.2 to $0.3 \mathrm{ml}$ of $3 \%$ sodium citrate down the cannula increased tonus and initiated contractions (Text-fig. 1). In nine of fourteen observations, the contractions had ceased and the tonus had returned to normal within 2 to $5 \mathrm{~min}$. In the remaining five observations, the contractions continued for $30 \mathrm{~min}$. 


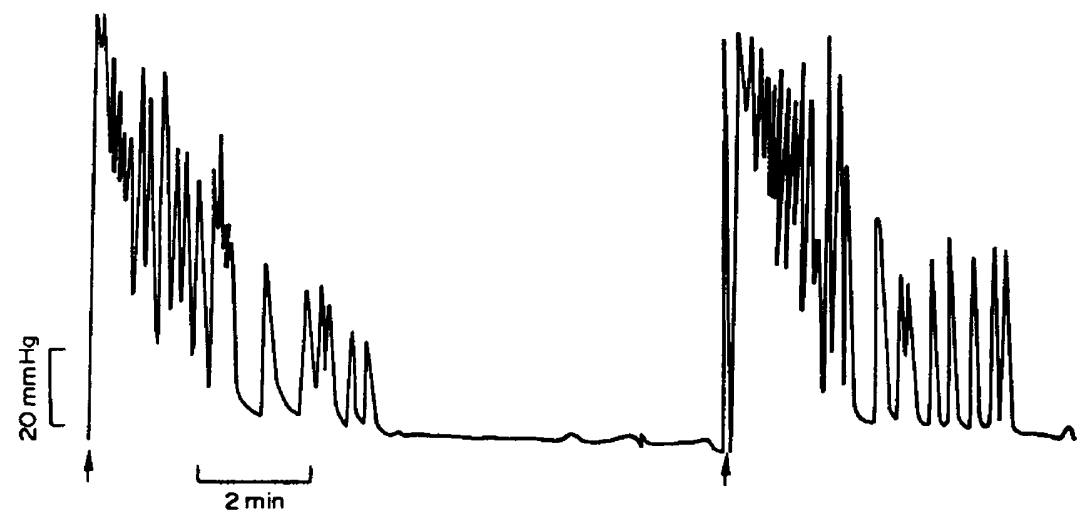

TExT-FIG. 1. The response of the cannulated ductus deferens-epididymis of an anaesthetized ram to mechanical stimulation. The arrows indicate the flushing of $0.2 \mathrm{ml}$ of $3 \%$ sodium citrate down the cannula.
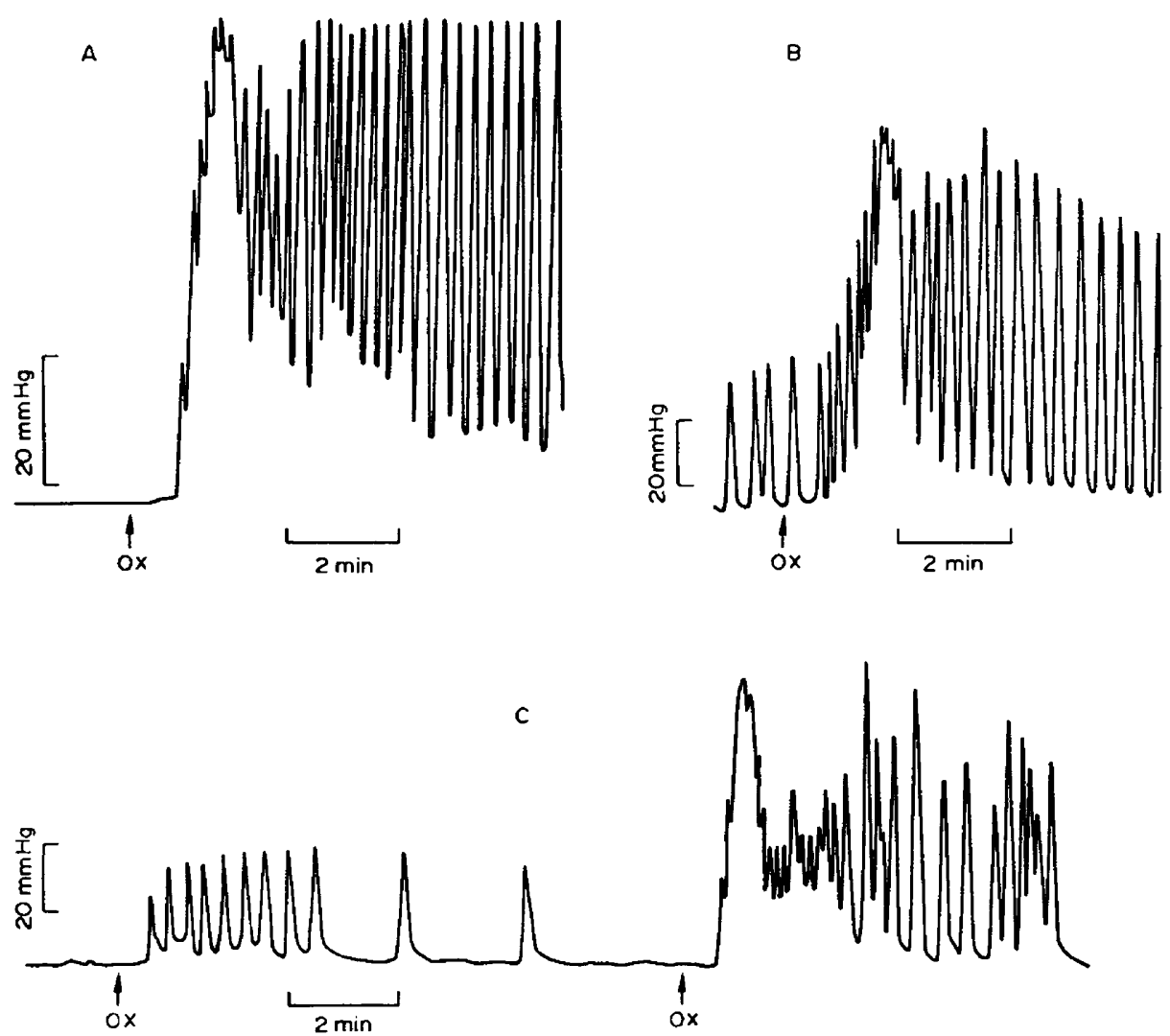

Text-FIg. 2. The intraluminal pressure changes in the cannulated ductus deferensepididymis of the ram. (A) and (B) The response to 10 i.u. oxytocin in anaesthetized rams. In (B), the peaks before the oxytocin injection were due to the injection of 2 i.u. oxytocin $16 \mathrm{~min}$ previously. (G) The responses to $\mathbf{0 . 3}$ i.u. oxytocin followed by 1 i.u. oxytocin in a conscious ram. Ox = Oxytocin injection. 
When each of the ductus deferens-epididymis of a ram was cannulated, the flushing of $3 \%$ sodium citrate down one cannula did not stimulate contractions on the contralateral side.

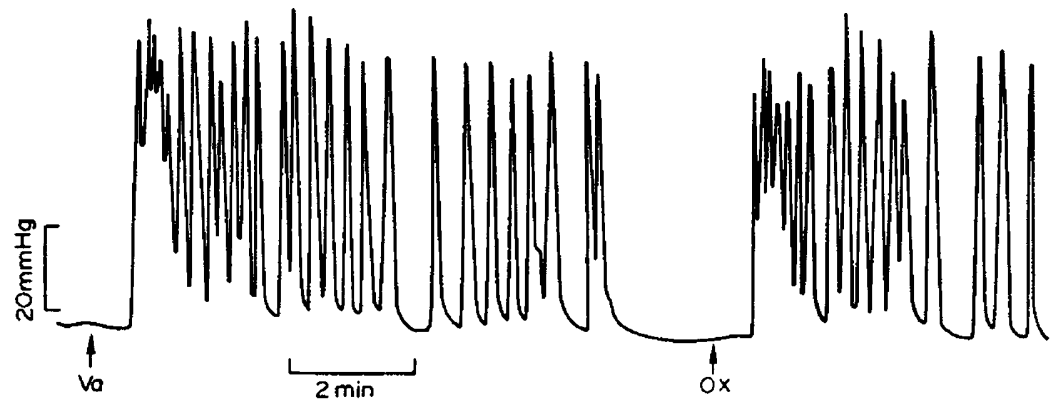

TExT-FIG. 3. The intraluminal pressure changes in the cannulated ductus deferensepididymis of a conscious ram. The response to $20 \mathrm{i}$.u. vasopressin followed by the response to 1 i.u. oxytocin. $\mathrm{Va}=$ Vasopressin injection; $\mathrm{Ox}=$ oxytocin injection.

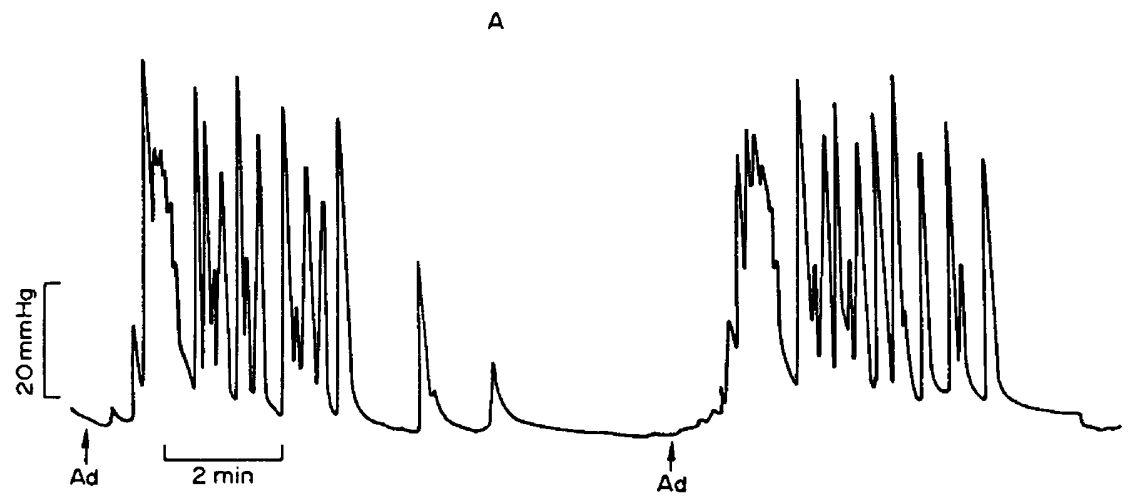

B

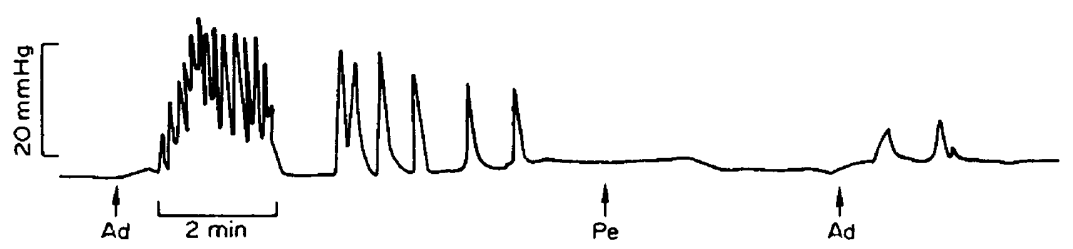

TEXT-FIG. 4. The intraluminal pressure changes in the cannulated ductus deferentesepididymides of anaesthetized rams. (A) The responses to $25 \mu \mathrm{g}$ adrenaline. (B) The response to $10 \mu \mathrm{g}$ adrenaline before and after the injection of $10 \mathrm{mg}$ phentolamine. $\mathrm{Ad}=$ Adrenaline injection; $\mathrm{Pe}=$ phentolamine injection.

The effect of oxytocin. Injections of $0 \cdot 3$ to 10 i.u. oxytocin initiated contractions and an increased tonus in the quiescent ductus deferens-epididymis, and increased the tonus and the amplitude and frequency of submaximal contractions (Text-fig. 2). The most prominent feature of the response to high doses of oxytocin ( 2 to 10 i.u.) was its long duration: the rhythmical contractions 
continued for 20 to $70 \mathrm{~min}$. Over this period, the amplitude and frequency of the contractions declined and became progressively more irregular. Following the injection of low doses of oxytocin ( 0.3 to 1 i.u.), the duration of the response was only 3 to $6 \mathrm{~min}$ and, in many cases, there were no increases in tonus (Textfig. 2).

The mean latency from the injection of oxytocin to the response, i.e. stimulation of contractions and/or tonus, was $45 \cdot 5 \pm 1 \cdot 2$ (S.E.) sec, and the mean duration of a muscular contraction, when the tonus was near the basal level,

A
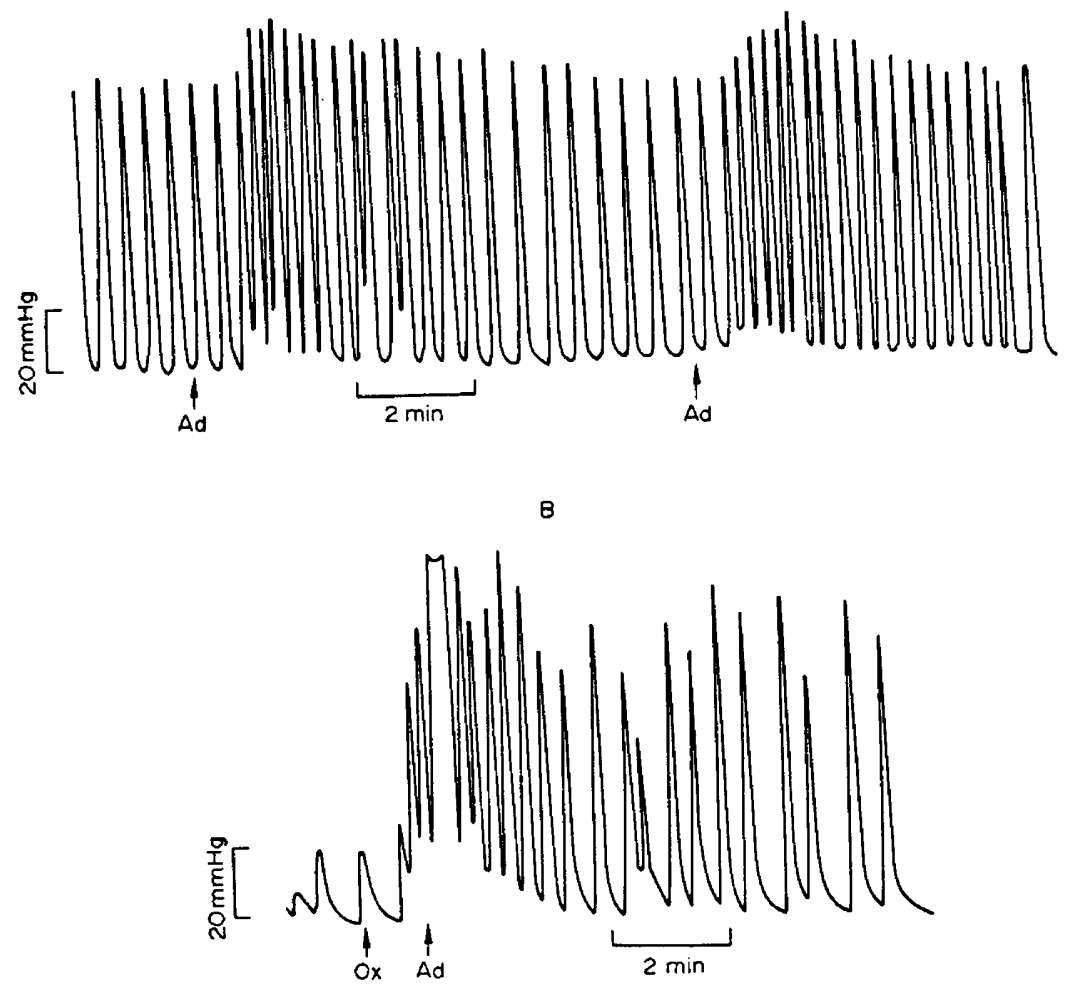

TEXT-FIG. 5. The intraluminal pressure changes in the cannulated ductus deferensepididymis of a conscious ram. (A) The responses to the injection of $40 \mu \mathrm{g}$ adrenaline. The pressure changes before the adrenaline injections are due to the injection of 5 i.u. oxytocin $15 \mathrm{~min}$ previously. (B) The response to the injection of $5 \mathrm{i} . \mathrm{u}$. oxytocin, followed $1 \mathrm{~min}$ later by the injection of $40 \mu \mathrm{g}$ adrenaline. Ad = Adrenaline injection; $\mathrm{Ox}=$ oxytocin injection.

was $15 \pm 0.7$ (S.E.) sec. After the injection of 2 to 10 i.u. oxytocin, the tonus increased and remained elevated for 2 to $6 \mathrm{~min}$. This increase in tonus included, in most cases, an initial peak of 20 to $120 \mathrm{mmHg}$ which returned to within 5 to $20 \mathrm{mmHg}$ in 1 to $1 \frac{1}{2} \mathrm{~min}$ (Text-fig. 2). The maximum frequency of contractions of 8 to 13 per min was observed when the tonus was rising to a peak and the amplitude of the contractions was at a minimum. As the tonus declined, the frequency of the contractions decreased to 3 to $4 \mathrm{per} \mathrm{min}$, while their amplitude increased (Text-fig. 2).

The effect of vasopressin. The injection of $20 \mathrm{i}$.u. vasopressin initiated a response 
similar in both tonus and contractions to the response to 0.5 to 1 i.u. oxytocin (Text-fig. 3). With low doses of 5 to $10 \mathrm{i} . \mathrm{u}$. vasopressin, only the most sensitive ductus deferens-epididymal preparations responded.

The effect of adrenaline. The striking difference between the response to adrenaline and to high doses of oxytocin was the short duration of the former (Textfigs 2 and 4). The contractions induced by adrenaline tended to have a more
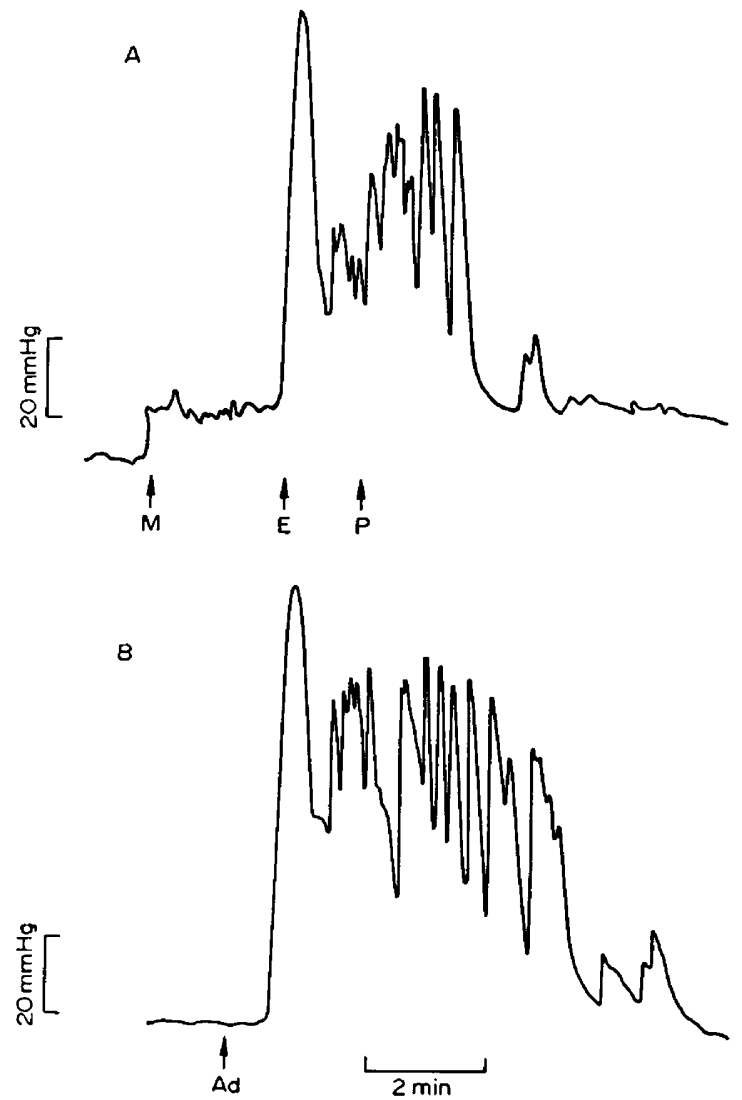

TEXT-FIG. 6. The pressure changes in the cannulated ductus deferens-epididymis of a conscious ram. (A) The response during copulation. (B) The response to $40 \mu \mathrm{g}$ adrenaline. Ad = Adrenaline injection; $M=$ mounting; $E=$ ejaculation; $P=$ post ejaculation.

irregular amplitude and frequency than the contractions induced by oxytocin although the maximum frequencies and amplitudes were similar. The mean latency from the injection of adrenaline to the response was $44 \cdot 1 \pm 1 \cdot 7$ (S.E.) sec.

Injection of adrenaline did not inhibit the response to oxytocin (Text-fig. 5). When there were contractions present from a previous oxytocin injection, the injection of adrenaline increased the frequency and amplitude of the contractions and increased the tonus (Text-fig. 5).

The effect of $\alpha$ - and $\beta$-receptor-blocking agents. The injection of 10 to $15 \mathrm{mg}$ of an 
$\alpha$-receptor-blocking agent (phentolamine) inhibited the response to adrenaline (Text-fig. 4) for 12 to $15 \mathrm{~min}$. There was no inhibition to the response to oxytocin or to the flushing of $0.3 \mathrm{ml}$ of $3 \%$ sodium citrate down the cannula into the epididymis.

The injection of 1 to $2 \mathrm{mg}$ of the $\beta$-receptor-blocking agents, propranolol and oxprenolol, had no effect on the response of the ductus deferens-epididymis to oxytocin or adrenaline.

The effect of pilocarpine and atropine. The injection of 50 to $100 \mathrm{mg}$ of the cholinergic stimulant, pilocarpine, produced no response in the ductus deferensepididymis. The injection of $10 \mathrm{mg}$ of the anticholinergic agent, atropine, did not inhibit the response to the injection of oxytocin.

Direct cannulation of the epididymis. The only difference between the response to oxytocin or adrenaline when the epididymis was directly cannulated compared to that when the ductus deferens-epididymis was cannulated was the lack of any large increase in tonus and the smaller amplitude of the contractions.

\section{Experiment 2}

In mating rams, sexual stimulation and mounting initiated irregular contractions and increased the tonus in the ductus deferens-epididymis (Textfig. 6). There was a single large contraction at ejaculation, followed by smaller, irregular contractions in the post-ejaculatory period. All contractions ceased 3 to $4 \mathrm{~min}$ after ejaculation, and by then the tonus had decreased to within $10 \mathrm{mmHg}$ of the basal level. The response did not resemble that to any dose of oxytocin or vasopressin but was similar to that induced by intravenous injections of 10 to $40 \mu \mathrm{g}$ adrenaline (Text-fig. 6).

\section{DISCUSSION}

The effects of intravenous injections of oxytocin on the ductus deferensepididymis of the ram contrast with those in the rabbit, in which high doses of oxytocin (100 mi.u. oxytocin/ $\mathrm{kg}$ liveweight) have no effect and low doses of oxytocin ( $20 \mathrm{mi} . \mathrm{u}$. oxytocin $/ \mathrm{kg}$ liveweight) only increase the amplitude of existing spontaneous contractions (Melin, 1970b).

The duration of the response to oxytocin in the ram was longer with high than with low doses of oxytocin. With 2 to 10 i.u., the contractions continued for 20 to $70 \mathrm{~min}$, which is many times longer than the reported half-life of oxytocin in the blood of most animals (Fitzpatrick, 1961). This long duration of the response to oxytocin suggests that the epididymis may bind the oxytocin and that the rate of inactivation of the bound oxytocin is much lower than that of oxytocin in the blood. Such an extended period of response to oxytocin was found also in the human uterus by Sica-Blanco \& Sala (1961), who suggested a similar binding and inactivation mechanism.

Vasopressin, which induced a response in the ductus deferens-epididymis of the ram similar to oxytocin, had only $1 / 15$ th to $1 / 20$ th the potency of oxytocin. Conversely, in the rabbit, Melin (1970b, c) found that vasopressin was more potent than oxytocin in stimulating the epididymis. The relative potencies of vasopressin and oxytocin in the ram are similar to their relative 
potencies in stimulating milk ejection in the rat (Bisset, Clark, Haldar, Harris, Lewis \& Rocha e Silva, 1967) and contraction of the uterus in the rabbit (Cross, 1958).

Adrenaline also induced contractions in the ductus deferens-epididymis of the ram but the duration of the response was much shorter than the duration of the response to high doses of oxytocin. The receptors stimulated by adrenaline were of the $\alpha$-type, since the response to adrenaline was inhibited by phentolamine. The response of the ductus deferens-epididymis to oxytocin was not inhibited by adrenaline. This contrasts with the response of the mammary gland and uterus in which adrenaline inhibits the response to oxytocin (Cross, 1958; Bisset et al., 1967).

Oxytocin appears to be acting on the epididymis directly and not through adrenergic or cholinergic fibres or receptors, since blocking agents for these did not inhibit the response to oxytocin. In addition, the cholinergic stimulant, pilocarpine, had no effect on the contractions of the epididymis.

Spontaneous contractions in the ductus deferens-epididymis of the ram appear to depend upon mechanical stimulation, i.e. the intraluminal pressure within the ductus deferens-epididymis, since the flushing of $3 \%$ sodium citrate down the cannula stimulated contractions of the ductus deferens-epididymis. The lack of response to the increase in pressure in the contralateral ductus deferens-epididymis and the lack of inhibition by phentolamine of the response to increased pressure in the ipsilateral ductus deferens-epididymis indicate that the response was not being mediated by the release of oxytocin or stimulation of the adrenergic nervous plexus. This contrasts with the ewe in which oxytocin was released by the distension of the genital tract (Roberts \& Share, 1968).

The contractions of the ductus deferens-epididymis observed immediately after the cannula was connected to the pressure transducer were possibly caused by the mechanical stimulation during cannulation.

There was a large peak in tonus in the ductus deferens-epididymis immediately following the injection of oxytocin or adrenaline. This peak could have been caused by the contraction of the ductus deferens since it was not present when the epididymis was directly cannulated. Previous work (Knight, 1972b) has suggested that oxytocin and adrenaline may initiate two to three large contractions of the ductus deferens.

The irregular contractions during sexual stimulation and mounting, and the large contractions during ejaculation, were probably caused by the nervous stimulation of the ductus deferens and epididymis. Cross \& Glover (1958) found in the rabbit that stimulation of the hypogastric nerve produced an immediate and intense contraction of the ductus deferens and cauda epididymidis with emission of spermatozoa from the cannulated ductus deferensepididymis.

The muscular contractions in the epididymis which continue for 3 to $4 \mathrm{~min}$ after ejaculation were probably due to the presence of adrenaline in the blood. Wojcik (1969) found that adrenaline was released into the blood of rams during copulation. This suggestion is strengthened by the strong similarity between the types of contractions induced by natural mating and by injections of 
adrenaline recorded in the second experiment. In the buck, Cross \& Glover (1958) found that stimulation of the dorsal, lateral and posterior areas of the hypothalamus not only stimulated the contractions of the ductus deferens, but also caused a release of adrenaline from the adrenal medulla.

There is no evidence from the results of the present study that oxytocin is released in the ram during copulation. Following ejaculation, there are no large regular contractions of long duration similar to those initiated by large doses of oxytocin, which could move the spermatozoa down the epididymis. This agrees with the evidence that sexual activity has only a slight effect on accelerating the transport of spermatozoa down the male genital tract (KoefoedJohnsen, 1960; Amir \& Ortavant, 1968).

\section{ACKNOWLEDGMENTS}

I would like to thank Dr D. R. Lindsay for his advice and $\mathrm{Mr} \mathrm{T}$. Johnson and $\mathrm{Mr}$ M. Sanders for their technical assistance. Financial assistance was provided by the Australian Meat Research Committee.

\section{REFERENCES}

Amrr, D. \& Ortavant, R. (1968) Influence de la fréquence des collectes sur la durée du transit des spermatozoïdes dans le canal épididymaire du bélier. Annls Biol. anim. Biochim. Biophys. 8, 195.

BANks, E. M. (1964) Some aspects of sexual behaviour in domestic sheep, Ovis aries. Behaviour, 23, 249.

BEREZNEv, A. P. (1963) Oxytocin-a stimulation in the semen production of bulls. Anim. Breed. Abstr. 33, 270.

Bisset, G. W., Clark, B. J., Haldar, J., Harris, M. C., Lewis, G. P. \& Rocha e Silva, M., JR (1967) The assay of milk ejecting activity in the lactating rat. Br. F. Pharmac. Chemother. $31,537$.

Gross, B. A. (1958) The motility and reactivity of the oestrogenized rabbit uterus in vivo with comparative observations on milk ejection. F. Endocr. 16, 237.

GRoss, B. A. (1959) Hypothalamic influences on sperm transport in the male and female genital tract. In Endocrinology of Reproduction, pp. 167-176. Ed. G. W. Lloyd. Academic Press, New York.

Cross, B. A. (1966) Neural control of oxytocin secretion. In Neuroendocrinology, pp. 217-259. Eds. L. Martini and W. F. Ganong. Academic Press, New York.

Cross, B. A. \& Glover, T. D. (1958) The hypothalamus and seminal emission. F. Endocr. 16, 385.

FitzPATRICK, R. J. (1961) The estimation of small amounts of oxytocin in the blood. In Oxytocin, pp. 360-369. Eds. R. Caldeyra-Barcia and H. Heller. Pergamon Press, Oxford.

FJeliström, D., Kinlström, J. E. \& Melin, P. (1968) The effect of synthetic oxytocin upon seminal characteristics and sexual behaviour in male rabbits. J. Reprod. Fert. 17, 207.

KNIGHT, T. W. (1972a) In vivo effects of oxytocin on the contractile activity of the cannulated epididymis and vas deferens in rams. 7. Reprod. Fert. 28, 141.

KNIGHT, T. W. (1972b) A study of factors which affect the potential fertility of rams. Ph.D. thesis, University of Western Australia.

KNIGHT, T. W. (1974) The short-term effects of intravenous injections of oxytocin and adrenaline on semen output of rams. F. Reprod. Fert. 39, 329.

KNIGHT, T. W. \& LINDSAY, D. R. (1970) Short and long-term effects of oxytocin on quality and quantity of semen from rams. F. Reprod. Fert. 21, 523.

Koefoed-Johnsen, H. H. (1960) Influence of ejaculation frequency on the time required for sperm formation and epididymal passage in the bull. Nature, Lond. 185, 49.

Meuin, P. (1970a) In vivo recording of contractile activity of male accessary genital organs in rabbits. Acta physiol. scand. 79, 109.

MeLin, P. (1970b) Effects in vivo of neurohypophysial hormone on the contractile activity of accessory sex organs in male rabbits. F. Reprod. Fert. 22, 283.

MELIN, P. (1970c) Effects of oxytocin on some sexual functions of male rabbits with special reference to the sperm transporting mechanism and sperm production. Abstr. Uppsala Diss.-Sci.

Milovanov, V. K., Bereznev, A. P. \& Gorohov, L. N. (1962) The effect of oxytocin on the reproductive system of male livestock. Anim. Breed. Abstr. 32, 101. 
Norberg, K. A., Risley, P. L. \& Ungerstedt, U. (1967) Adrenergic innervation of the male reproductive ducts in some mammals. I. The distribution of adrenergic nerves. Z. Zellforsch. mikrosk. Anat. 76, 278.

Roberts, S. R. \& Share, L. (1968) Oxytocin in plasma of pregnant, lactating and cycling ewes during vaginal stimulation. Endocrinology, 83, 272.

Sica-Blanco, Y. \& Sala, N. L. (1961) Uterine contractility at the beginning and end of an oxytocin infusion. In Oxytocin, pp. 127-136. Eds. R. Caldeyra-Barcia and H. Heller. Pergamon Press, Oxford.

Simeone, F. A. (1933) A neuromuscular mechanism in the ductus epididymidis and its impairment by sympathetic denervation. Am. 7. Physiol. 103, 582.

Sjöstrand, N. O. (1965) The adrenergic innervation of the vas deferens and the accessory male genital glands. Acta physiol. scand. 65, Suppl. 257.

Wojcik, K. (1969) Mechanizm przesuwania sie plemnikow w meskich narzadach plciowych. III. Kurizliwosc nasieniowodow u tryka $\mathrm{w}$ czasie powstrzymywanej kopulacji. Zesz. nauk. wyzsz. Szk. roln., Krakow, No. 20. 